\title{
Long term management of glycogen storage disease type 1b: a Brazilian tertiary center experience
}

\author{
Marina Mayumi Vendrame TAKA0 ${ }^{1}$, Natascha Silva SANDY², \\ Adriana Gut Lopes RICCETTO ${ }^{1}$ and Adriana Maria Alves DE TOMIMASO ${ }^{1}$
}

Received: 5 September 2020 Accepted: 3 November 2020

ABSTRACT - Background - Glycogen storage disease (GSD) type $1 \mathrm{~b}$ is a multisystemic disease in which immune and infectious complications are present, in addition to the well-known metabolic manifestations of GSD. Treatment with granulocyte-colony stimulating factor (G-CSF) is often indicated in the management of neutropenia and inflammatory bowel disease. Objective - To report on the demographics, genotype, clinical presentation, management, and complications of pediatric patients with glycogen storage disease type $1 \mathrm{~b}$ (GSD 1b), with special attention to immune-related complications. Methods - Retrospective case series of seven patients with GSD 1b diagnosed and followed at a tertiary university hospital in Brazil, from July/2000 until July/2016. Results - Mean age at referral was fourteen months. Diagnosis of GSD 1b was based on clinical and laboratory findings and supported by genetic studies in five cases. All patients presented suffered from neutropenia, managed with G-CSF - specifically Filgrastim. Hospitalizations for infections were frequent. Two patients developed inflammatory bowel disease. Six patients remained alive, one died at age 14 years and 9 months. The mean age at the end of the follow-up was 11.5 years. Compliance to treatment was suboptimal: poor compliance to medications, starch and dietetic management of GSD were documented, and outpatient appointments were frequently missed. Conclusion - Managing GSD $1 \mathrm{~b}$ is challenging not only for the chronic and multisystemic nature of this disease, but also for the additional demands related dietary restrictions, use of multiple medications and the need for frequent follow-up visits; furthermore in Brazil, the difficulties are increased in a scenario where we frequently care for patients with unfavorable socioeconomic status and with irregular supply of medications in the public health system.

HEADINGS - Glycogen storage disease type I. Neutropenia. Inflammatory bowel diseases. Immune system diseases. Granulcyte colony-stimulating factor. Filgrastim. Pediatrics.

\section{INTRODUCTION}

Glycogen storage diseases (GSD) are a group of rare inherited disorders caused by different enzymatic defects in the glycogen metabolism. The severity of the disease is highly variable according to type and degree of the enzyme activity impairment. GSD type 1 has a reported incidence of $1 / 100.000$ live births ${ }^{(1)}$, with two major subtypes: the most frequent is 1a, which corresponds to $80 \%$ of cases and is determined by mutations in the glucose- 6 phosphatase gene $^{(2)}$, and GSD type $1 \mathrm{~b}$ is the second most important and frequent subtype, and it is caused by mutations in the glucose- 6 phosphatase translocase gene (SLC37A4 gene, also known as G6PT1 gene) ${ }^{(2)}$. To this date, no Brazilian long term follow-up studies on GSD 1b have been published - there are, however, Brazilian studies on the molecular and clinical characterization of GSD $1 \mathrm{a}^{(3)}$ and a crosssectional analysis on GSD types $1 \mathrm{a}$ and $1 \mathrm{~b}^{(4)}$.

In glycogen storage disease type $1 \mathrm{~b}$ (GSD 1b), besides the clinical and laboratorial manifestations that are common to GSD type 1a (hepatomegaly, the characteristic "doll-like" face with "fat cheeks", short stature, hypoglycemia, lactic acidosis, hypertriglic- eridemia, and hyperuricemia), patients also develop neutropenia and neutrophil dysfunction ${ }^{(5-9)}$, leading to increased susceptibility to infections. The pathogenesis of neutropenia in GSD $1 \mathrm{~b}$ remains poorly understood. Different mechanisms have been proposed: increased production of reactive oxygen species ${ }^{(10)}$, abnormal neutrophil differentiation ${ }^{(6-11)}$, shorter neutrophil lifespan ${ }^{(6,12)}$ and abnormal cytokine profiles ${ }^{(8,13)}$. Furthermore, neutrophils from patients with GSD 1b present abnormal mobility, chemotaxis, calcium mobilization, respiratory burst and phagocyte activity ${ }^{(7,14)}$.

Granulocyte colony-stimulating factor (G-CSF), a hematopoietic growth factor essential for the neutrophil differentiation and function, has been used for approximately 3 decades as pharmacological agent to increase neutrophil count, lifespan, and activation. Its efficacy and safety as a long term therapy for patients with GSD $1 \mathrm{~b}$ was proven: it significantly reduces the rates of recurrent bacterial infections and enterocolitis in this particularly susceptible population ${ }^{(15)}$.

The aim of the present study was to report on the demographics, genotype, clinical presentation and management of pediatric patients presenting with GSD $1 \mathrm{~b}$, as well as to characterize complications and clinical course on their follow-up.

Declared conflict of interest of all authors: none

Disclosure of funding: no funding received

Guarantor of the article: Adriana Maria Alves de Tommaso.

${ }^{1}$ Universidade Estadual de Campinas (Unicamp), Faculdade de Ciências Médicas, Departamento de Pediatria, Campinas, SP, Brasil. ${ }^{2}$ Division of Gastroenterology, Hepatology and Nutrition Department of Pediatrics - Hospital for Sick Children, University of Toronto. Toronto, ON, Canada.

Corresponding author: Adriana Gut Lopes Riccetto. E-mail: agut@unicamp.br 


\section{METHODS}

A retrospective chart review of all pediatric patients with GSD 1b, who were diagnosed and/or followed at the Clinics Hospital, University of Campinas - São Paulo, Brazil, from July/2000 to July/2016, was conducted. Subjects were identified from a patient registry kept by the senior author. The study was approved by the Research Ethics Committee of University of Campinas Clinics Hospital under Certificate number 61819516.8.00005404, approval number 1.846 .888 .

Two investigators (Takao MMV and Sandy NS) collected data from the medical records including: gender, date of birth, age and type of initial manifestations, genotype, laboratorial data (alanine aminotransferase, blood glucose, lactate, triglycerides, uric acid, and neutrophil count), number of infections requiring hospitalization, use of G-CSF use of antibiotic prophylaxis, and comorbidities. Summary statistics was used to describe the data.

\section{RESULTS}

Seven patients were included in the study, five were male, and two patients were siblings. The median age at referral was eleven months. The diagnosis of GSD 1b was based on clinical and laboratory findings, as well as liver biopsy, and later supported by next generation sequencing DNA analysis (confirmed by Sanger sequencing) in five cases. Genetic testing was not performed for all patients, since this is not routinely available in our public healthcare system - this type of request is reserved for selected/atypical cases, upon clear justification of its need, and approval of the indication. Gender, age of symptoms onset, age of referral, symptoms of presentation and genotype (when available) data is summarized in TABLE 1. There was a delay between symptoms onset and referral. Hypoglycemia was universally reported at presentation, in association with seizures in five cases.

During long term follow-up, there was significant variation in terms of metabolic control: hypoglycemia, hypertriglyceridemia, hyperlactatemia, hyperuricemia and elevated transaminases were often document. TABLE 2 summarizes the broad variation in the main laboratory test results - critically abnormal results can be noted.

Persistent and severe neutropenia (defined as less than 500 neutrophils per microliter in peripheral blood) was treated with G-CSF, specially Filgrastim, in all cases. The median age for initiation of G-CSF was 5 years. None of the patients developed any serious adverse G-CSF side effect requiring discontinuation of this treatment: one patient developed splenomegaly as side effect, managed with reduction of dosage. Four of the seven patients also received prophylactic antibiotics. Despite those measures, hospitalizations due to recurrent infections were frequent. Worst documented neutropenia, age of G-CSF initiation, number and causes of hospitalizations due to infections and use of antibiotic prophylaxis are summarized on TABLE 3.

TABLE 1. Gender, age of symptoms onset, age of referral, symptoms of presentation and genotype.

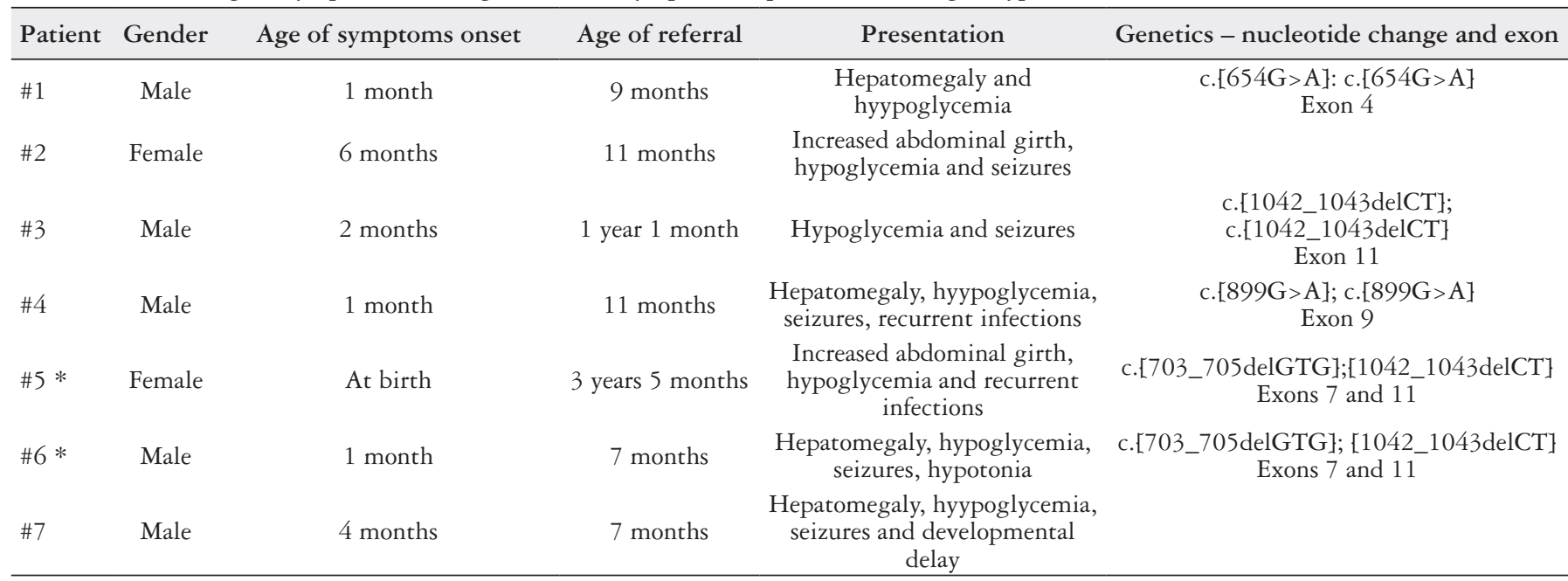

* Patients \#5 and \#6 are siblings.

TABLE 2. Summary of the range of variation of the main metabolic laboratory results.

\begin{tabular}{lccccc}
\hline Patient & $\begin{array}{c}\text { Lactate } \\
(\mathrm{mg} / \mathrm{dL})\end{array}$ & $\begin{array}{c}\text { Alanine } \\
\text { Aminotransferase (U/L) }\end{array}$ & $\begin{array}{c}\text { Uric acid } \\
(\mathrm{mg} / \mathrm{dL})\end{array}$ & $\begin{array}{c}\text { Triglycerides } \\
(\mathrm{mg} / \mathrm{dL})\end{array}$ & $\begin{array}{c}\text { Glycemia } \\
(\mathrm{mg} / \mathrm{dL})\end{array}$ \\
\hline$\# 1$ & $1.2-5.3$ & $2-68$ & $3.7-15.3$ & $57-1447$ & $3-108$ \\
$\# 2$ & $1.9-48.2$ & $14-81$ & $5.6-9.6$ & $120-600$ & $56-112$ \\
$\# 3$ & $1.9-6.9$ & $26-76$ & $2.5-6.3$ & $269-1192$ & $3-181$ \\
$\# 4$ & $2.2-7.4$ & $11-214$ & $4.3-7.5$ & $99-390$ & $48-11$ \\
$\# 5$ & $3.3-9.3$ & $29-113$ & $6.2-8$ & $185-562$ & $22-142$ \\
$\# 6$ & $2.3-11.7$ & $51-1556$ & $5.5-10.4$ & $71-1361$ & $15-91$ \\
\hline 7 & $1.2-14.9$ & $7-92$ & $5.9-14.1$ & $91-666$ & $38-150$ \\
\hline
\end{tabular}


TABLE 3. Most severe neutropenia, age of G-CSF initiation, history of hospitalizations due to infections, use of antibiotic prophylaxis.

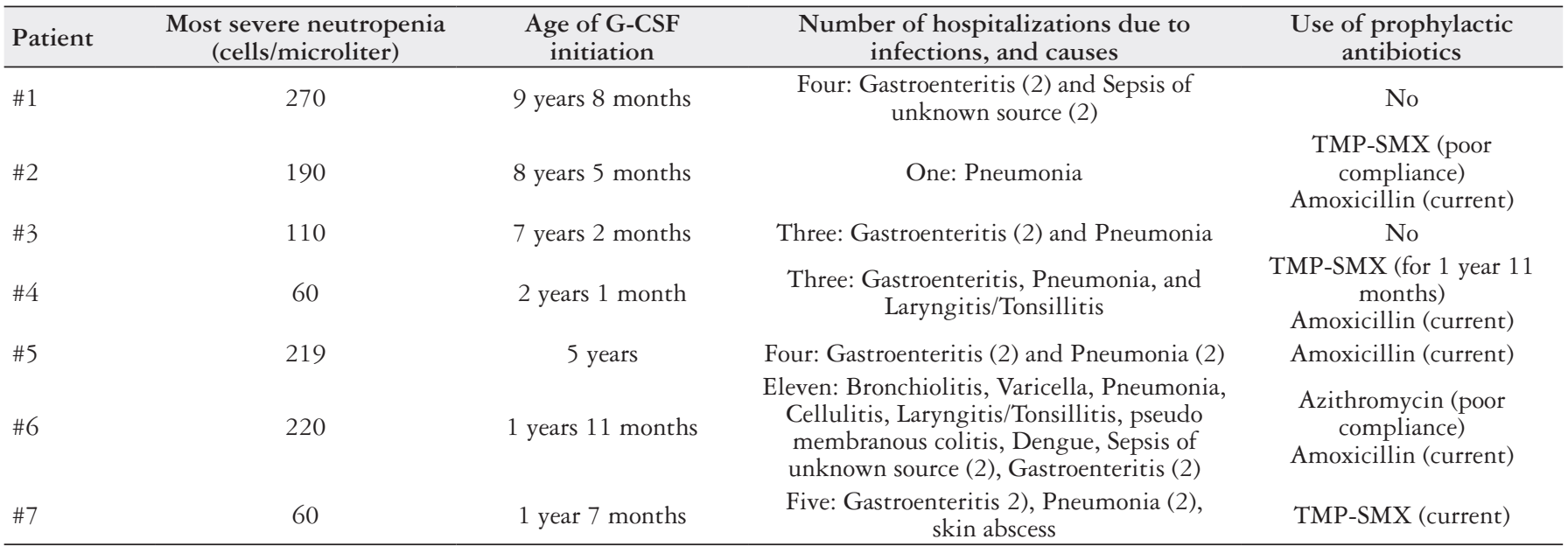

G-CSF: granulocyte colony-stimulating factor; TMP-SMX: trimethoprim-sulfamethoxazole.

In our study population, compliance was sub-optimal follow-up appointments were frequently missed, medications were irregularly administered, poor compliance to starch and dietetic restrictions were documented. In most cases, socioeconomic vulnerability was an important aggravating factor related to poor compliance. Two patients developed Crohn-like Inflammatory Bowel Disease, confirmed by colonoscopy and were mainly managed with G-CSF, but also required intermittent use of systemic corticosteroids. Additionally, atopic manifestations were frequently noted: three patients developed allergic rhinitis and asthma, and one also presented atopic dermatitis. All patients were monitored with annual ultrasounds as part of surveillance for hepatic adenoma, a well-known complication in GSD1 ${ }^{(16)}$ : detected in one of our patients, who as asymptomatic and did not develop any complications. The tumor was better characterized with a computed tomography study: solid hyperdense lesion with arterial hypervascularization noted in the hepatic segment $\mathrm{V}$, measuring $1.3 \times 1.2 \mathrm{~cm}$. This lesion has been monitored with ultrasound every six months and no significant growth was noted thus far. The first patient diagnosed at our Institution died at age 14 years and 9 months, due to sepsis of unknown origin. At the end of the study follow-up, six patients remained alive, with a median age of 11 years. Compliance, associated conditions, and age at the end of follow-up period are summarized on TABLE 4.

\section{DISCUSSION}

To this date, more than a hundred mutations in the SLC37A4 determining GSD $1 \mathrm{~b}$ have been described, according to The Human Gene Mutation Database ${ }^{\circledR}$, and novel mutations continue to be reported. With a broader use of molecular techniques to support the diagnosis and management of GSD, a genotype-phenotype correlation in regards to the severity of the neutropenia has been explored, but not well described so far ${ }^{(15,17)}$. All mutations noted in our patients have been previously described, and no inference in terms genotype-phenotype correlation could be established in our case series.

TABLE 4. Compliance, associated conditions, and age at the end of follow-up period.

\begin{tabular}{|c|c|c|c|}
\hline Patient & Description of compliance & Associated conditions & Age at the end of follow-up \\
\hline$\# 1$ & $\begin{array}{l}\text { Poor: frequently missed follow-up visits, irregular use of } \\
\text { G-CSF. }\end{array}$ & $\begin{array}{c}\text { IBD } \\
\text { Cataract } \\
\text { Osteoporosis } \\
\text { Severe malnutrition }\end{array}$ & Died at 14 years 9 months \\
\hline$\# 2$ & $\begin{array}{l}\text { Regular: missed some follow-up visits, irregular timing in } \\
\text { the use of starch, poor compliance to some medications. }\end{array}$ & $\begin{array}{l}\text { Asthma } \\
\text { Allergic rhinitis } \\
\text { Constipation }\end{array}$ & 15 years \\
\hline \#3 & $\begin{array}{l}\text { Regular: periodically irregular routine with the use of } \\
\text { starch and medications, but never missed follow-up visit; } \\
\text { predominantly suboptimal metabolic control. }\end{array}$ & $\begin{array}{l}\text { Asthma } \\
\text { Allergic rhinitis } \\
\text { Atopic dermatitis }\end{array}$ & 13 years \\
\hline$\# 4$ & Regular: irregular use of G-CSF. & $\begin{array}{l}\text { IBD } \\
\text { Urticaria }\end{array}$ & 10 years \\
\hline \#5 & $\begin{array}{l}\text { Poor: frequently missed follow-up visits, predominantly poor } \\
\text { metabolic control. }\end{array}$ & None & 12 years \\
\hline \#6 & $\begin{array}{l}\text { Poor: frequently missed consultations; predominantly poor } \\
\text { laboratory control; irregular compliance to starch and dietary } \\
\text { recommendations; refusal to use prophylactic antibiotics. }\end{array}$ & Anemia & 9 years \\
\hline
\end{tabular}

G-CSF: granulocyte colony-stimulating factor; IBD: inflammatory bowel disease. 
The primary treatment for GSD type 1 is diet therapy: fructose, lactose, and sucrose are avoided, while raw cornstarch is given enterally to prevent hypoglycemia. In GSD $1 b$, the abnormal neutrophil count and function adds another layer of complexity to the management of the disease: a variety of infectious complications are frequent in patients with GSD $1 \mathrm{~b}$, including infections affecting the upper and lower respiratory tracts, gastrointestinal and genitourinary tracts, skin and mucous membranes, deep abscesses and sepsis of unknown origin. The main agents involved are staphylococci, streptococci and Escherichia coli ${ }^{(5,18)}$. In the present study, the infections that most often required hospitalizations for treatment were pneumonia and gastroenteritis.

Prophylactic antibiotics are often used in patients with recurrent infections and neutropenia. The benefits of such intervention have been broadly demonstrated outside of GSD $1 \mathrm{~b}$. It became an official recommendation of the European 2002 Consensus Guideline for the management of GSD 1, even though it was recognized that these benefits were not specifically systematically studied in $\mathrm{GSD}^{(18)}$. More recently published, the practice guideline of the American College of Medical Genetics and Genomics did not provide any recommendations in that specific subject ${ }^{(16)}$. Cotrimoxazole or trimethoprim-sulfamethoxazole (TMP-SMX) is typically the antibiotic of choice ${ }^{(18)}$. In the present case series, the use of TMP-SMX was initially used in three of the seven cases, however due to poor compliance and mainly complaints of gastrointestinal intolerance, it was changed to Amoxicillin in some cases.

On a different note, there is a growing interest in the use of probiotics in GSD 1b, but the evidence remains anecdotal ${ }^{(19)}$. More studies are needed to first more broadly the changes in the composition of the gut microbiota in GSD 1b, and later identify whether there will be any specific indications for probiotics in this group of patients. A national study has reported dysbiosis in $\mathrm{GSD}^{(20)}$, and this finding was later corroborated in an Italian study ${ }^{(21)}$. As the knowledge in this area is still evolving, probiotics may be costly and are not routinely available in our public health system in Brazil, none of the patients in the present cohort used probiotics.

Granulocyte colony-stimulating factor is one of the cornerstones in the management of GSD 1b. Its use not only has positive impact in the neutrophil count and severity of recurrent infections (particularly recurrent bacterial infections and enterocolitis) ${ }^{(15)}$, but it also constitutes an important component in the treatment of the Inflammatory Bowel Disease in GSD $1 b^{(8)}$. In the present study, we observed laboratory and clinical response in all patients. In our cohort, the mean age of initiation of G-CSF was 5 years, in keeping with previous studies that reported development of severe neutropenia at the median age of 4.5 years $^{(17)}$. With prolonged use of G-CSF in neutropenic patients, the following complications have been reported: 1) hypersplenism, splenomegaly ${ }^{(18)}$, and splenic rupture $^{(22,23)}$ - probably resulting from extramedullary hematopoiesis; 2) bone health related complications - transient or persistent bone pain, and osteopenia/osteoporosis ${ }^{(2,25)}, 3$ ) transient hematologic complications - monocytosis, eosinophilia, reticulocytosis, and thrombocytopenia; 4) risk of neoplasms - prolonged stimulation of the bone marrow may predispose to leukemic transformation ${ }^{(26)}$; 5) loss of response to treatment; 6) and other less often reported complications - chronic urticaria, hepatic adenomas, polycystic ovaries, increased uric acid, leukocytoclastic vasculitis; bloodproliferative glomerulonephritis. Thus, the use of this medication requires careful surveillance and constant re-evaluation of the risks and benefits ${ }^{(27)}$, and there is a growing interest in G-CSF sparing strategies. In this case series, as in other studies ${ }^{(17)}$, no serious adverse events related to the use of G-CSF were observed, as recommended, all patients were regularly monitored by clinical and laboratory evaluations.

It has been suggested that vitamin $\mathrm{E}$ also has a role in improving neutrophil count and reducing the frequency and severity of infections, and its effectiveness in reducing the frequency of infection and improving neutropenia has been reported in GSD $1 \mathrm{~b}$ patients ${ }^{(28)}$. Although it is easy to argue that vitamin E supplementation would have many advantages over the use of G-CSF, in terms of route of administration (oral vs subcutaneous, respectively) and safety/adverse effects, its use as a strategy to reduce or avoid G-CSF has not been systematically studied, and the current evidence is considered insufficient to recommend routine use of vitamin E supplementation alone as a G-CSF sparring strategy. In the GSD 1 practice guideline of the American College of Medical Genetics and Genomics vitamin E is mentioned under "other dietary considerations", but it is not officially recommended. Considering the relative low cost and safety of this intervention, all our patients have been on daily vitamin E (doses of $400 \mathrm{UI} /$ day), however in none of the cases that intervention has clearly led to significant weaning of G-CSF. Assessment of vitamin E levels in our patients was not routinely done, as unfortunately this specific laboratory assessment is not customarily available in our public health system. Another therapy recently explored is the off-label use of an SGLT2-inhibitor, empagliflozin, typically used to treat type 2 diabetes. It was reported to successfully treat neutropenia and neutrophil dysfunction in GSD 1b, allowing weaning and even discontinuation of G-CSF ${ }^{(29)}$. This therapy was not attempted in any of our patients.

Besides neutropenia and neutrophil dysfunction, patients with GSD $1 \mathrm{~b}$ may experience lymphopenia, impaired regulatory $\mathrm{T}$ cell function ant autoimmunity. The exact mechanism for autoimmunity in these patients is still not well described ${ }^{(30)}$, but several studies have reported an increased risk for autoimmune disorders, including Inflammatory Bowel Disease (IBD), thyroid autoimmunity, and myasthenia gravis. Two of our patients developed IBD (Crohn disease-like enterocolitis): one of the patients presented with recurrent episodes of vomiting and diarrhea at six years of age, that later progressed to chronic diarrhea, while the second patient presented chronic diarrhea at 18 months. The association between GSD $1 \mathrm{~b}$ and IBD has been reported since the late 1970s, and later a high prevalence of IBD was noted in GSD (up to $77 \%)^{(8)}$. G-CSF is the mainstay therapy for IBD in GSD 1b, but not all patients respond to $i^{(16)}$. Other therapies, such as salicylates, mesalamine, sulfasalazine and prednisone may be necessary ${ }^{(15)}$. In our two cases, steroids were temporarily used (prednisone up to $1 \mathrm{mg} / \mathrm{kg}$ ), with no associated complications/side effects with a short term course of this medication. No other autoimmune diseases were noted in our cohort of patients.

GSD 1b management requires frequent follow-up appointments, regular use of medications and a restricted diet, with scheduled use of cornstarch. Education about the disease has a fundamental role for treatment compliance. Outpatient visits in our institution are coordinated to include at least a dietician and the pediatric Immunology and Hepatology medical teams at each visit. Furthermore, a psychologist is available for patients and caregivers on demand or when recommended by the medical teams. Annual educational and social events for patients/caregivers have been organized. Despite all those measures, suboptimal compliance is the 
reality in most of the cases. More than the well-known difficulties of caring for a chronic disease, the irregular supply of medications by our public health system, and unfavorable socioeconomic conditions had a negative impact on treatment compliance.

Our study has the well-known limitations of retrospective design, and additionally our cohort encompasses almost two decades of care, when there were significant changes in the understanding and therefore in the management of GSD 1b. Nonetheless, this is the first long term follow-up pediatric GSD 1b case series in Brazil, in which we report a wide spectrum of disease severity, complications and associated conditions, as well as we discuss current recommendations for GSD $1 \mathrm{~b}$ treatment. Severe neutropenia was universally present, and all patients were treated with G-CSF, nevertheless, infectious diseases requiring hospitalizations were relatively common. The early recognition and medical management of sepsis is fundamental in GSD $1 \mathrm{~b}$ to avoid a potentially fatal outcome, as in these patients not only neutrophil count is affected, but also neutrophil function is impaired. In the present cohort of patients, managing GSD $1 \mathrm{~b}$ was noted to be challenging not only for the chronic and multisystemic nature of this disease, requiring multiple medical and dietary interventions, but also complicated by non-medical risk factors, namely socioeconomic vulnerability.

\section{Authors' contribution}

Takao MMV and Sandy NS conceptualized the article, obtained REB approval, collected the data, drafted the initial manuscript, reviewed and revised the manuscript, approved the final draft as submitted. Riccetto AGL contributed to the manuscripts, reviewed and revised the manuscript, approved the final draft as submitted. De Tommaso AMA supervised throughout all the different phases of this study, analyzed the data, reviewed and revised the manuscript, and approved the final draft as submitted.

\section{Orcid}

Marina Mayumi Vendrame Takao: 0000-0002-9430-7817.

Natascha Silva Sandy: 0000-0002-7744-8984.

Adriana Gut Lopes Riccetto: 0000-0002-1330-3591.

Adriana Maria Alves De Tommaso: 0000-0001-7077-9804.

Takao MMV, Sandy NS, Riccetto AGL, De Tommaso AMA. Manejo em longo prazo de glicogenose tipo 1b: experiência de um centro terciário brasileiro. Arq Gastroenterol. 2021;58(1):87-92.

RESUMO - Contexto - Glicogenose (GSD) tipo 1b é uma doença multissistêmica em que complicações imunológicas e infecciosas estão presentes, além das manifestações metabólicas bem conhecidas da GSD. O tratamento com fator estimulador de colônias de granulócitos (G-CSF) é frequentemente indicado no tratamento da neutropenia e doença inflamatória intestinal. Objetivo - Relatar sobre a dados demográficos, genótipo, apresentação clínica, manejo e complicações de pacientes pediátricos com GSD tipo 1b (GSD 1b), com atenção especial às complicações relacionadas ao sistema imunológico. Métodos - Série de casos retrospectiva de sete pacientes com GSD 1b diagnosticados e acompanhados em um hospital universitário terciário no Brasil, de julho/2000 a julho/2016. Resultados - A idade média no encaminhamento foi de 14 meses. O diagnóstico de GSD 1b foi baseado em achados clínicos e laboratoriais e apoiado por estudos genéticos em cinco casos. Todos os pacientes apresentaram neutropenia, tratada com G-CSF - especificamente Filgrastim. As hospitalizações por infecções foram frequentes. Dois pacientes desenvolveram doença inflamatória intestinal. Seis pacientes permanecem vivos, um morreu aos 14 anos e 9 meses de idade. A média de idade ao final do acompanhamento foi de 11,5 anos. A adesão ao tratamento foi sub-ótima: má adesão aos medicamentos, amido e manejo dietético de GSD foram documentados, e consultas ambulatoriais foram frequentemente perdidas. Conclusão - O manejo da GSD 1b é um desafio, não apenas pela natureza crônica e multissistêmica desta doença, mas também pelas demandas adicionais relacionadas a restrições dietéticas, uso de múltiplos medicamentos e a necessidade de consultas de acompanhamento frequentes; no Brasil, isso ainda é dificultado em um cenário em que frequentemente atendemos pacientes com situação socioeconômica desfavorável e com oferta irregular de medicamentos no sistema público de saúde.

DESCITORES - Doença de depósito de glicogênio tipo I. Neutropenia. Doenças inflamatórias intestinais. Doenças do sistema imunitário. Fator estimulador de colônias de granulócitos. Filgrastim. Pediatria.

\section{REFERENCES}

1. Chou JY, Jun HS, Mansfield BC. Type I glycogen storage diseases: disorders of the glucose-6-phosphatase/glucose-6-phosphate transporter complexes. J Inherit Metab Dis. 2015;38:511-9.

2. Chou JY, Mansfield BC. Mutations in the glucose-6-phosphatase-alpha (G6PC) gene that cause type Ia glycogen storage disease. Hum Mutat. 2008;29:921-30.

3. de CRF, Caldas HC, Norato DY, Schwartz IV, Giugliani R, Burin MG, Sartorato EL. Glycogen storage disease type Ia: molecular study in Brazilian patients. J Hum Genet. 2001;46:146-9.

4. Santos BL, Souza CF, Schuler-Faccini L, Refosco L, Epifanio M, Nalin T, et al Glycogen storage disease type I: clinical and laboratory profile. J Pediatr (Rio J). 2014;90:572-9.

5. Melis D, Fulceri R, Parenti G, Marcolongo P, Gatti R, Parini R, et al. Genotype/ phenotype correlation in glycogen storage disease type $1 \mathrm{~b}$ : a multicentre study and review of the literature. Eur J Pediatr. 2005;164:501-8.

6. Chou JY, Jun HS, Mansfield BC. Neutropenia in type Ib glycogen storage disease. Curr Opin Hematol. 2010;17:36-42.
7. Jun HS, Weinstein DA, Lee YM, Mansfield BC, Chou JY. Molecular mechanisms of neutrophil dysfunction in glycogen storage disease type Ib. Blood. 2014; 123:2843-53.

8. Visser G, Rake JP, Fernandes J, Labrune P, Leonard JV, Moses S, et al. Neutropenia, neutrophil dysfunction, and inflammatory bowel disease in glycogen storage disease type Ib: results of the European Study on Glycogen Storage Disease type I. J Pediatr. 2000;137:187-91.

9. Choi R, Park HD, Ko JM, Lee J, Lee DH, Hong SJ, et al. Novel SLC37A4 Mutations in Korean Patients With Glycogen Storage Disease Ib. Ann Lab Med. 2017;37:261-6.

10. Kim SY, Nguyen AD, Gao JL, Murphy PM, Mansfield BC, Chou JY. Bone marrow-derived cells require a functional glucose 6-phosphate transporter for normal myeloid functions. J Biol Chem. 2006;281:28794-801.

11. Sim SW, Weinstein DA, Lee YM, Jun HS. Glycogen storage disease type Ib: role of glucose-6-phosphate transporter in cell metabolism and function. FEBS Lett. 2020;594:3-18. 
12. Kuijpers TW, Maianski NA, Tool AT, Smit GPA, Rake JP, Roos D, Visser G Apoptotic neutrophils in the circulation of patients with glycogen storage disease type 1b (GSD1b). Blood. 2003;101:5021-4.

13. Dieckgraefe BK, Korzenik JR, Husain A, Dieruf L. Association of glycogen storage disease $1 \mathrm{~b}$ and Crohn disease: results of a North American survey. Eur J Pediatr. 2002;161 (Suppl 1):S88-92.

14. Kim SY, Jun HS, Mead PA, Mansfield BC, Chou JY. Neutrophil stress and apoptosis underlie myeloid dysfunction in glycogen storage disease type Ib. Blood 2008;111:5704-11.

15. Dale DC, Bolyard AA, Marrero T, Kelley ML, Makaryan V, Tran E, et al Neutropenia in glycogen storage disease Ib: outcomes for patients treated with granulocyte colony-stimulating factor. Curr Opin Hematol. 2019;26:16-21.

16. Kishnani PS, Austin SL, Abdenur JE, et al. Diagnosis and management of glycogen storage disease type I: a practice guideline of the American College of Medical Genetics and Genomics. Genetics in Medicine. 2014;16(11):e1-e1.

17. Sarajlija A, Djordjevic M, Kecman B, Skakic A, Pavlovic S, Pasic S, Stojiljkovic M. Impact of genotype on neutropenia in a large cohort of Serbian patients with glycogen storage disease type Ib. Eur J Med Genet. 2019;63:103767.

18. Visser G, Rake JP, Labrune P, Leonard JV, Moses S, Ullrich K, et al. Consensus guidelines for management of glycogen storage disease type $1 \mathrm{~b}$ - European Study on Glycogen Storage Disease Type 1. Eur J Pediatr. 2002;161 (Suppl 1):S120-123.

19. Carnero-Gregorio M, Molares-Vila A, Corbalán-Rivas A, Villaverde-Taboada C, Rodríguez-Cerdeira C. Effect of VSL\#3 Probiotic in a Patient with Glycogen Storage Disease Type Ia and Irritable Bowel Disease-like Disease. Probiotics Antimicrob Proteins. 2019;11:143-9.

20. Colonetti K, Bento Dos Santos B, Nalin T, Moura de Souza CF, Triplett EW, Dobbler PT, et al. Hepatic glycogen storage diseases are associated to microbial dysbiosis. PLoS One. 2019;14:e0214582.

21. Ceccarani C, Bassanini G, Montanari C, Casiraghi MC, Ottaviano E, Morace $\mathrm{G}$, et al. Proteobacteria Overgrowth and Butyrate-Producing Taxa Depletion in the Gut Microbiota of Glycogen Storage Disease Type 1 Patients. Metabolites. 2020;10:133.
22. Masood N, Shaikh AJ, Memon WA, Idress R. Splenic rupture, secondary to G-CSF use for chemotherapy induced neutropenia: a case report and review of literature. Cases J. 2008;1:418.

23. Benguerfi S, Thepault F, Lena H, Ricordel C. Spontaneous splenic rupture as a rare complication of G-CSF injection. BMJ Case Rep. 2018;2018: bcr2017222561. doi: 10.1136/bcr-2017-222561.

24. Kokai Y, Wada T, Oda T, Kuwabara H, Hara K, Akiyama Y, et al. Overexpression of granulocyte colony-stimulating factor induces severe osteopenia in developing mice that is partially prevented by a diet containing vitamin K2 (menatetrenone). Bone. 2002;30:880-5.

25. Sekhar RV, Culbert S, Hoots WK, Klein MJ, Zietz H, Vassilopoulou-Sellin R. Severe osteopenia in a young boy with Kostmann's congenital neutropenia treated with granulocyte colony-stimulating factor: suggested therapeutic approach Pediatrics. 2001;108(3):E54.

26. Li AM, Thyagu S, Maze D, Schreiber R, Sirrs S, Stockler-Ipsiroglu S, et al Prolonged granulocyte colony stimulating factor use in glycogen storage disease type $1 \mathrm{~b}$ associated with acute myeloid leukemia and with shortened telomere length. Pediatr Hematol Oncol. 2018;35:45-51.

27. Rosenberg PS, Alter BP, Bolyard AA, Bonilla MA, Boxer LA, Cham B, et al. The incidence of leukemia and mortality from sepsis in patients with severe congenital neutropenia receiving long-term G-CSF therapy. Blood. 2006;107:4628-35.

28. Melis D, Minopoli G, Balivo F, Marcolongo P, Parini R, Paci S, et al. Vitamin E Improves Clinical Outcome of Patients Affected by Glycogen Storage Disease Type Ib. JIMD Rep. 2016;25:39-45.

29. Wortmann SB, Van Hove JLK, Derks TGJ, Chevalier N, Knight V, Koller A, et al. Treating neutropenia and neutrophil dysfunction in glycogen storage disease IB with an SGLT2-inhibitor. Blood. 2020;136:1033-43.

30. Melis D, Carbone F, Minopoli G, Rocca CL, Perna F, De Rosa V, et al. Cutting Edge: Increased Autoimmunity Risk in Glycogen Storage Disease Type 1b Is Associated with a Reduced Engagement of Glycolysis in T Cells and an Impaired Regulatory T Cell Function. J Immunol. 2017;198:3803-8. 